Vi har valgt at bringe en erindringsartikel skrevet af Hans Flintholm Hansen om hans tid som en del af modstandsbevægelsen i Sønderjylland 1943-44 og om arrestationen og fængslingen af ham. I artiklen beskriver han også sit ophold i Frøslevlejren, og hvordan han oplevede turen med De hvide Busser gennem Danmark til Sverige. Jens-Christian Hansens artikel om de danske fanger i koncentrationslejren HusumSchwesing i Sydslesvig er baseret på resultaterne fra hans ph.d.-afhandling. Lejren var en udelejr til Neuengamme, og fangerne blev sat til at grave tankspærringer i forbindelse med den såkaldte Friservold. Selv om lejren ved Husum kun eksisterede i tre måneder i efteråret 1944, var der en meget høj dødelighed blandt fangerne - også blandt de danske. I den sidste artikel kortlægger Adrian Schaefer-Rolffs politikken i forhold til det tyske mindretal i Sønderjylland og det danske i Sydslesvig. Han har gennemført en interviewundersøgelse, og analyserer, hvordan mindretalspolitikken på hver side af grænsen har fungeret inden for de seneste år, og hvordan mindretalslederne vurderer dens betydning.

I år bringes der ni boganmeldelser. Det er lidt færre end de foregående år, hvilket skyldes, at vi har lavet en aftale med Sønderjysk Månedsskrift om, at vi i årbogen alene anmelder større, faglige bogudgivelser, mens bøger med et bredere formidlingssigte anmeldes i Månedsskriftet. I dette års årbog er oversigten over de lokalhistoriske tidsskrifter af ressourcemæssige årsager gledet $\mathrm{ud}$.

God læselyst!

\section{Den gale præst}

\section{Johannes Oldendorph og hans selvbiografi ${ }^{1}$}

Af Thomas Bonnemann EgebæK

Præsten Johannes Oldendorph levede 1524-1566, og han var til tider svær at omgås. Flere gange blev han fyret fra sine stillinger både i England og Haderslev på grund af sit iltre temperament. Hans selvbiografi indeholder mange detaljer og beskrivelser af dagliglivet og hoffet i Haderslev under Hertug Hans den Ældre. Selvbiografien er et personligt indblik i en præsts mentalitet, kærlighedsliv og følelser i en tid, hvor selvbiografier ofte havde karakter af kalendere. På trods af de mange kvaliteter har bogen endnu ikke fået en fuld gennemarbejdelse i nyere tid.

\section{Indledning}

En pestsyg præst ligger for døden i Haderslev. Han hører Jesus tale til sig: "Den, som tror på mig, vil gennem denne død gå over til evigt liv." ${ }^{2}$ Med et sæt vækkes han af sin spæde datters gråd og skrig. Hun ligger og kæmper med en stor pestbyld, som ikke er blevet bedre, siden kirugen skar et stykke af den. ${ }^{3}$ Dagen efter forstår præsten, at hans tid er kommet til at møde Herren og Kristus. De sidste ord nedskrives i bogen, som han efterhånden har arbejdet på i tre år. Han er ikke i tvivl; "Mine skrifter viser klart, hvad der har været min kristne tro og bekendelse efter det Guds ord, som er overleveret os gennem profeterne og apostlene. Amen."4 To dage senere er han død.

Præsten hed Johannes Jacobsen Oldendorph og han levede fra 1524 til 1566. Hans liv er skildret i en slægtshistorie, selvbiografi og dagbog, som han påbegyndte i 1563 og slutter ved hans død. Den er blandt de ældste selvbiografier i Danmark, og den er sammenhængende. Johannes Oldendorphs selvbiografi giver os et indblik i en tid, præget af uenighed om forståelsen af Christian III's lutherske reformation i 1536. Samtidig får læserne et enestående indblik i de sociale og politiske forhold i Haderslev set med et par lutherske præsteøjne. Det er derfor underligt, hvorfor Oldendorphs selvbiografi dårligt er kendt på et nationalt plan, og at den næsten kun er blevet anvendt i et sønderjysk perspektiv. Bogens tilgængelighed har ikke været et problem siden 1966, da Historisk Samfund for Sønderjylland udgav den latinske tekst 


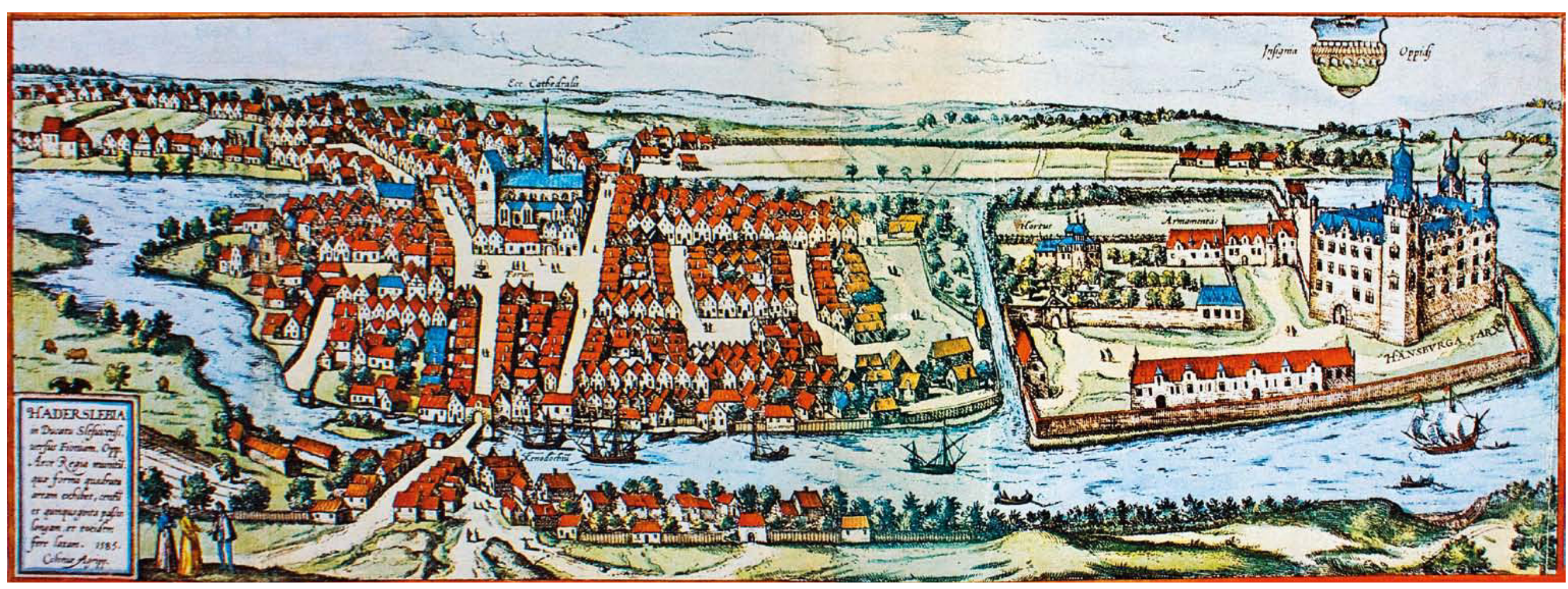

i en dansk oversættelse. Derfor bør en gennemgang af selvbiografien kunne åbne op for en bredere forståelse og anvendelse af bogen som kilde til følelses- og dagligliv omkring midten af 1500-tallet.

En ejendommelig mand

Oldendorphs dagbog/selvbiografi er første gang brugt som historisk kilde af den anerkendte teolog Holger Frederik Rørdam, der var optaget af Oldendorphs rejse til København i Kirkehistoriske Samlinger fra 1868. Rørdam beskriver den haderslevske præst som "...en yderst stridbar karakter, fuld af høje tanker om sin egen dygtighed, og at han derfor i reglen bedømmer de personer, han traf sammen med, på en meget ensidig og ofte vist ganske ubillig måde. ${ }^{\prime \prime}$ Lignende beskrivelse af Oldendorph findes hos den sønderjyske historiker, Thomas Otto Achelis, der i sit tobindsværk om Haderslevs historie beskriver præsten som "...en lærd mand, men - som lærde folk undertiden kan være - var han sommetider lidt skør i hovedet." ${ }^{\prime \prime}$ Samtidig havde Achelis ikke meget til overs for Oldendorphs selvbiografi da "Det er i og for sig ikke særlig værdifulde optegnelser, Hans Jacobsen Oldendorph har efterladt sig." ${ }^{\prime 7}$ Beskrivelsen af Oldendorph er dog mere moderat i forordet til oversættelsen af hans selvbiografi, hvor oversætteren, præsten A. Andersen, beskriver ham som "...en ejendommelig og lidet omgængelig mand, overbevist om sit eget værd og hård i bedømmelsen af andre." ${ }^{\prime 8}$ M. Favrholdt fortsætter denne tendens i sin bog om Haderslev Latinskoles historie, når han bruger Oldendorph som eksempel på grammatikforgudelse i præstestanden. Han beskriver med hårde ord præsten som "...en opblæst pendant..." og "...en lærd nar...". ${ }^{9}$ Mere positiv indstillet er Mikkel Leth Jespersen, som i sin bog fra 2010 om hertug Hans den Ældres fyrstestat henviser til den ældre litteraturs hårde dom over Oldendorph: "Kildeværdien af kapellanens optegnelser kan dis- 
kuteres - ikke mindst fordi det er blevet hævdet, at manden var skør."10 Jespersen selv nuancerer dog kritikken med henvisning til et brev fra hertugen, hvori Oldendorph bl.a. beskrives som "en fin lærd mand" og gør brug af Oldendorph som kilde til hoflivet i Haderslev.

Den øvrige faglitteratur har været mistroisk over for Johannes Oldendorphs troværdighed og dermed anvendelsen af hans selvbiografi som kilde grundet hans psykiske sygdom. Hvis en person er psykisk ustabil eller decideret syg, skal historikeren stille sig særligt kritisk over for kildeværdien af vedkommendes skrifter.

Derfor fortjener Oldendorphs selvbiografi en mere fyldig udlægning, hvis vi vil stille de rigtige spørgsmål. En sådan udlægning vil fremvise en plaget mands fortælling, som der bør tages forholdsregler for at bruge.

\section{Født ind i god stand}

Johannes Oldendorph blev født ind i en velstående familie i Haderslev. Faderen, Jacob Petersen Oldendorph, var forretningsdrivende og blev senere borgmester i Haderslev. Af søskende havde han fire søstre, Marina, Ingeborg, Anna og Catharina samt to brødre, Nicolaus og Peter. Moderen, Elsebe, døde i 1526 to år efter hans fødsel, og faderen forblev enkemand indtil sin død i 1546. Oldendorph skriver intet om sin barndom, men begynder først sine erindringer med året 1545, da han studerede i Wittenberg. På denne tid herskede de store reformatorer Martin Luther og Philipp Melanchthon på universitetet. Johannes Oldendorph overværede flere prædikener af de to lærde mænd, men flygtede tilbage til Haderslev i 1546. Martin Luthers død samme år indvarslede begyndelsen på den Schmalkaldiske Krig mellem de evangeliske fyrsters forbund og den katolske tysk-romerske kejser Karl V. Krigen var et resultat af, at det schmalkaldiske fyrsteforbund var blevet en for stor magtfaktor i det tysk-romerske rige. Først efter at Karl V havde sluttet fred med Frankrig i 1544, var der mulighed for og midler til at føre krig imod det schmalkaldiske fyrsteforbund.

Kejseren havde indgået forbund med pave Paul III mod de protestantiske fyrster. Forbundet vægrede sig i 1546 ved at sende repræsentanter til koncilet i Trento, hvor paven lyste Johan Frederik I af Sachsen og Philipp I af Hessen fredløse. Herefter rasede krigen indtil 1547, hvor Karl V's tropper besejrede den schmalkaldiske forbundshær i slaget på Lochauer Heide. ${ }^{11}$
Det var disse uroligheder, der fik Oldendorph til at rejse hjem. Efter et kort ophold ved Rostock Universitet måtte han afbryde sine studier, da hans broder, Peter, i Kiel havde fået kidnappet sin hustru. I to år rejste brødrene rundt til Rostock, Wismar og Schwerin for at finde hende. Undervejs forklarede Peter, at hustuen var blevet kidnappet på grund af en pengegæld, som han havde pådraget sig.

\section{En lovende karriere}

Rejsen med broderen førte Johannes Oldendorph til Lübeck, hvor han mødte den polske reformator Johannes Laski. Han var en højtstående lærd, der var på vej til England, hvor Edward VI viste velvilje over for reformatoriske tanker og idéer. Han anmodede Laski om en anbefaling til en from herre og Laski svarede, at han ikke kendte nogen frommere end selveste ærkebiskoppen af Canterbury, Thomas Cranmer.

Johannes Oldendorph fik en anbefaling, men set i bagklogskabens lys skulle han ikke have taget imod den, da det senere kom frem, at Laski og Cranmer var velvilligt indstillet over for den zwinglianske reformati-

Thomas Cranmer (1489-1556) var ærkebiskop og Oldendorphs overordnede under hans ophold $i$ England.

Malet af Gerlach Flicke i 1545.

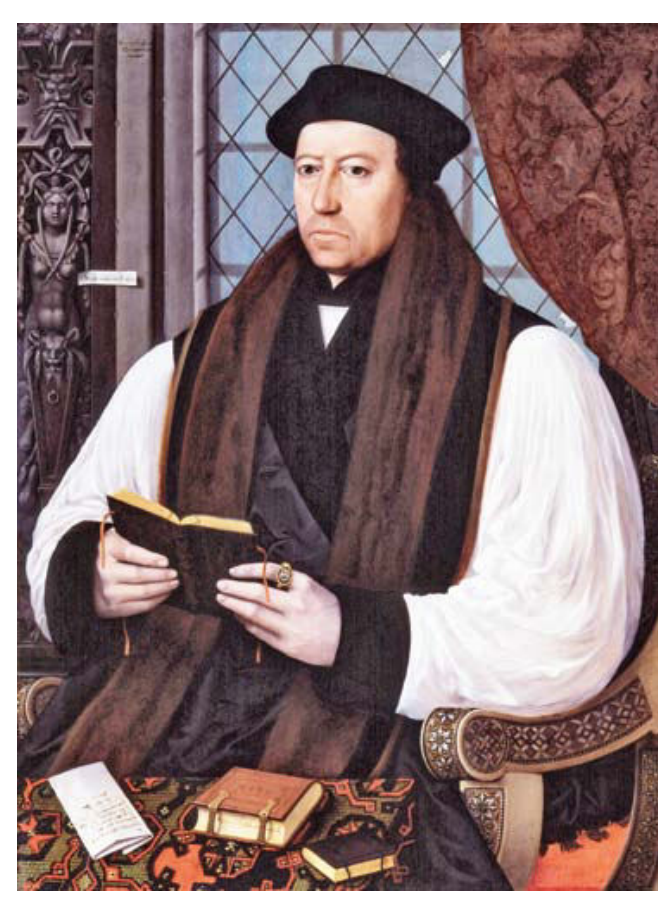


onslære. Oldendorph var jo selv oplært af Luther og Melanchthon, som havde en helt anden opfattelse af reformationen. Under reformationerne i Europa op til midten af 1500-tallet herskede der tre retninger, der hver havde deres egen forståelse af nadveren. For schweizeren Huldrych Zwingli (1481-1531) var nadveren rent symbolsk. ${ }^{12}$ Martin Luther (14831546) holdt derimod fast $i$, at Kristus kommer til mennesket gennem brødet og vinen ved indstiftelsesordene og er virkeligt nærværende. ${ }^{13}$ Derfor skal nadveren hos lutherdommen forstås sådan, som den lyder i Biblen og aldrig i en ren symbolsk betydning. Den franske Jean Calvin (1509-1564) tog en form for mellemposition, idet han forstod Kristi nærvær som en åndelig tilstedeværelse, hvor Jesus kun var til stede ånden. ${ }^{14}$ Herved ændrede Calvin ved Biblens fremstilling af nadveren.

I dag kan disse uenigheder virke som petitesser, men i begyndelsen af 1500-tallet var nadverforståelsen årsag til voldsomme intellektuelle konflikter. Oldendorphs forståelse af nadveren skulle senere vise sig at få stor betydning for hans liv og embede.

\section{Sygdommen bryder ud}

$\mathrm{Nu}$ artede Johannes Oldendorphs liv sig sådan, at han efter kort ophold i sin hjemby, Haderslev, rejste til England for at tjene ved Thomas Cranmers hof i det fornemme Lambeth Palace tæt på London. I begyndelsen af august 1549 rejste han med skib fra Hamborg og ankom til England 14 dage efter. Ved ankomsten til Lambeth Palace modtog Thomas Cranmer den haderslevske præst med ordene: "Du er mig meget velkommen; du skal være min amanuensis [skriver og kopist], og jeg vil give dig en god løn." ${ }^{15}$ Allerede her mistænkte Oldendorph ærkebiskoppen for at være zwinglianer, da han ikke svarede på følgende udbrud: "Højærværdige herre, med Guds hjælp og bistand vil jeg samvittighedsfuldt og trofast passe mine studier. Gid der i dette rige ikke var så mange vranglærere, zwinglianere og gendøbere, som jeg daglig hører!"16 Denne mistanke var velberettiget, da Thomas Cranmer i 1556 blev brændt for forræderi og kætteri af den katolske Dronning Maria I af England. Oldendorphs mistro til zwinglianister og gendøbere fortsatte igennem hele hans liv.

Oldendorph fik til opgave at sammenskrive en stor samling af uddrag fra kirkefædrene Dionysius, Ignatius, Polycarp, Irenæs, Tertullian og Cyprian. Under opholdet hos Thomas Cranmer skete der dog noget, som skulle påvirke ham resten af livet; han begyndte at blive syg. Det begyndte med paranoide vrangforestillinger om hans kollega, Peter Alexander, som læssede større arbejdsbyrder på ham, end han kunne bære. Hurtigt udviklede sagen sig til intenst mundhuggeri mellem de to lærde, og det blev så slemt, at ærkebiskoppen måtte gribe ind og forsøge at mægle mellem dem. Lige meget hjalp det, indtil ærkebiskoppen tilkaldte flere biskopper og andre lærde for at høre deres sag. Det lykkedes at forlige Oldendorph og Alexander, men samme aften ved et efterfølgende festmåltid blev Johannes Oldendorph stærkt afkræftet og mistænkte Peter Alexander for at have fyldt gift i glasset. Kort efter flyttede Oldendorph ud af Lambeth Palace til en enkeværtindes hus, hvor Peter Alexander kom for at tale med Oldendorph om det arbejde, han havde forladt. Midt i samtalen fór Oldendorph i flint og afrev i raseri noget af Alexanders skæg, og som han selv skriver: "...noget af det [skægget] viste han [Peter Alexander] til ærkebiskoppen, resten samlede jeg op fra gulvet og har gemt det for mig selv."17

Herefter blev det meget værre med Oldendorphs mentale og fysiske tilstand. Præsten lagde sig syg hos værtinden, og Djævelen kom for at give ham åndelige anfægtelser. Ifølge ham selv lykkedes det ham med stærk tro på Guds vilje at komme sig så meget, at han kunne rejse hjem til Haderslev i august 1550. Hjemme lå han syg i yderligere 14 dage hos en Villads Knutzen, indtil han faldt i en dyb søvn. Da Oldendorph vågnede, mærkede han ingen skade af sit vanvid eller sindsforstyrrelse og fortsatte sit virke i Haderslev.

\section{Kapellan ved Haderslev Domkirke}

Der skulle gå næsten seks år før Johannes Oldendorph fik et fast embede som præst. I 1556 blev han bedt om at forvalte kapellanembedet med ansvar for kapellet og begravelser i Haderslev Domkirke. Flere prominente personer var til stede ved hans indsættelse blandt andet provst Jørgen Boie, kirkeværgerne Hieronymus Boldigk og svogeren, borgmester Olaus Jensen, samt sognepræsten Johannes Vorstius. Indtil 1556 havde han kun holdt sporadiske prædikener i Haderslev på både tysk og dansk, men han havde endnu ikke haft et fast embede.

Oldendorph beholdt sin stilling som kapellan i seks år indtil 1562, da problemerne tårnede sig op om ham. Igennem sin tid som kapellan havde han skabt sig fjender både i byrådet og ved hertug Hans den Ældres hof. Hvordan, nævner han ikke helt præcist, men noterer eksempelvis: "År 1558 havde jeg også mange ubehageligheder i kapel- 
lanembedet og gav dem en opsigelse af stillingen, men de bad mig indstændigt om at blive." ${ }^{\prime 18}$

I løbet af 1561 fik han og den nyansatte sognepræst, Johannes Hecht, problemer med byrådet, kirkeværgerne Hieronymus Boldigk og borgmester Olaus Jensen samt provsten Jørgen Boie. Oldendorph og sognepræsten begyndte begge at opfordre folk til at give offer og betale for ligprædikener. ${ }^{19}$ Kirkeværgerne og byrådet gik imod denne handling, men Oldendorph anklagede dem for at bruge kirkens sten til eget byggeri og fordel. Tumulten blev kun større, da Oldendorph indgav sin opsigelse tre gange, men byrådet accepterede den ikke.

Hans problemer sluttede ikke her, og han blev indkaldt til Haderslevs bibliotek den 29. december 1561. Her måtte han stå skoleret over for byrådet, to borgmestre, kirkeværgerne, hertugens sekretær, byfogeden, flere sognepræster og prominente borgere. Borgmesteren Olaus Jensen holdt en tale, der formanede præsterne om at være evangeliets tjenere og ikke forsøge at skabe sig ekstra profit på deres embede. Oldendorph svarede skarpt igen: "Hvorfor vil du smigre for Satan og løgn og begære tak af Djævelen, når du har fremstillet de virkelige forhold? Jeg derimod har sagt, at det er Kristi bud i Matthæus 10, at en arbejder skal have sin løn. Endvidere 1. Korinterbrev vers 9: Herren har bestemt, at de, der står i evangeliets tjeneste skal leve af evangeliet." ${ }^{20}$

Derpå indgav han sin opsigelse endnu engang, men besluttede sig igen for at blive, da nogle af byrådsmedlemmerne blev kede af hans beslutning. I løbet af 1562 fik Johannes Oldendorph flere ansættelsestilbud fra Jørgen Boie og Johannes Hecht, men han ønskede stadigvæk at forlade Haderslevs kapellanembede til fordel for en stilling som sognepræst. Han afslog en stilling på nonneklosteret i Preetz samt sognepræsteembedet i både Preetz og Brügge. Vi ved at hertug Hans den Ældre skrev til sin amtmand Christoffer Rantzau omkring ansættelsen af Oldendorph i Brügge, da vi har et brev fra den 19. februar 1562. I brevet skriver hertugen om problemerne med den nuværende præst i Brügge og, hvordan Oldendorph kunne være en god erstatning. Samtidig får vi en enestående beskrivelse af ham som person:

"Hvis ikke det skulle være sket hidtil, så er det vores mening, at det er på tide at sige det, at vi til gavn for dette kirkesogn har en fin lært mand, Johannes Oldendorph, som på dette sted i lang tid har været kapellan, hvor han har opført sig velbegavet og godt såvel i lærdom som i livet." ${ }^{\prime 2}$
Hertugen beskriver Oldendorph som en fin og lærd mand, der har en god livsførelse og udfører god lære, altså vil han kunne udføre præsteembedet i Brügge med protestantisk lære. Betydningen af hertug Hans den Ældres beskrivelse er todelt. På den ene side kan det være, at hertugen rent faktisk synes om Oldendorph og virkelig gerne ville se ham som præst i Brügge. På den anden side kan det være et forsøg på at få Oldendorph ud af Haderslev. Derfor skriver hertugen denne salgstale for at overbevise amtmanden og Brügges borgere om, at Oldendorph er godt kvalificeret til embedet. Vi finder aldrig et endegyldigt svar på hertugens egentlige bagtanker, og lige meget hjalp brevet, da Oldendorph afslog stillingerne i både Preetz og Brügge for at blive i Haderslev.

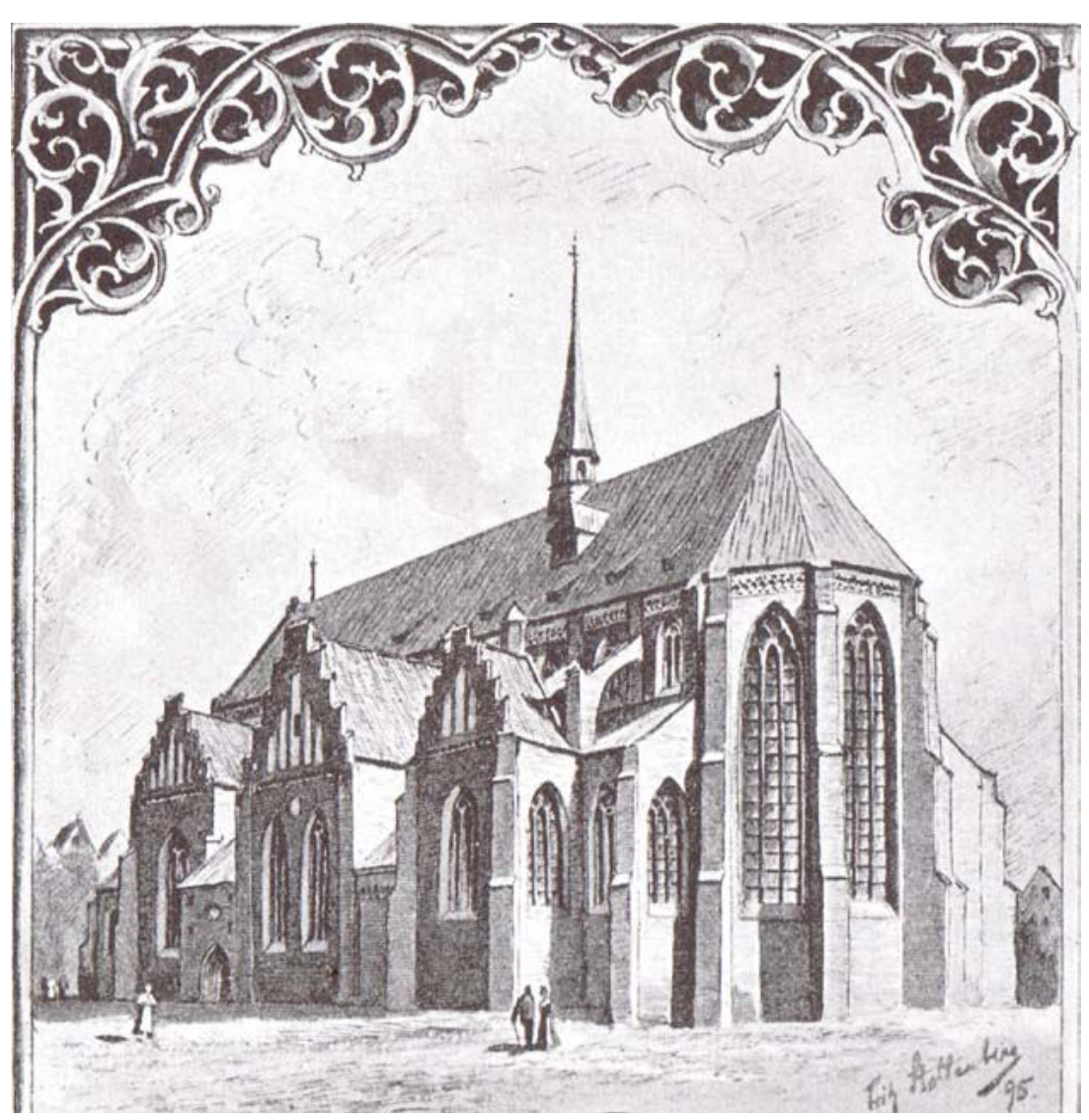

Vor Frue kirke i Haderslev var Oldendorphs arbejdsplads i hans år som kapellan. Tegning af Fritz Stoltenberg ca. 1895. 


\section{Fyringen}

I slutningen af marts 1562 mødte Johannes Oldendorph den "durchlauchtige fyrste hertug Hans af Holsten på Naffet [gade i Haderslev, der førte til slottet Hansborg]." 22 Det er bemærkelsesværdigt at selvbiografien indtil nu har været skrevet på latin, men samtalerne med hertug Hans skriver han på tysk. De talte om de gudsforagtere, som ville smide præsterne ud af Haderslev, hvortil hertugen svarede: "Hvad har de at udsætte på mine præster? Jeg vil ikke lade jer forlade mit land."23

Med denne vished i sit sind gik Oldendorph til et møde dagen efter med byrådet og borgerne. Han krævede en lønforhøjelse og istandsættelse af kapellanboligen mod at blive som kapellan i Haderslev. De lovede ham, at det nok skulle ske, men allerede den 3. april satte provst Boie et rænkespil i værk for at få kapellanen fyret. Samme dag mødte degnen Grejs op i Oldendorphs hus og bad ham forlade kapellanboligen. De to følgende dage forsøgte borgerne via et bønskrift til hertugen at beholde ham, men på grund af deres mangel på rygrad formåede de ikke at overlevere bønskriftet til fyrsten, ${ }^{24}$ og kapellanen måtte den 6 . april flytte sine ejendele til sin broders hus.

Således mistede Johannes Oldendorph sin stilling, og han skulle aldrig få et embede igen. De sidste fire år af hans liv levede han af sin arvede formue, men det forhindrede ham ikke i at fortsætte sit virke som prædikant og luthersk evangelist.

\section{Rejsen til København}

Efter sin fyring boede Oldendorph hos sin broder indtil juni 1562, da han besluttede at rejse til København for at besøge sin anden broder og overvære disputser på universitetet. Rejsen tog otte dage og gik over Odense og Roskilde.

Kort efter sin ankomst drog Johannes Oldendorph til universitetet, hvor han indledte en offentlig disput med magister Johannes Sascerides om kilderne til trøst ud fra teologien og filosofien. Da professoren og teologen Niels Hemmingsen så, at Sascerides var ved at bukke under for Oldendorphs argumentation, begyndte Hemmingsen selv at svare. Dette gik heller ikke så godt, og Oldendorph overvandt dem begge. Blandt publikum lød det: "Hemmingsen har nu en skarp modstander og disputator." ${ }^{\prime 25}$ Et par dage efter var de to igen i disput, hvor Hemmingsen forvirret vaklede. Disse udlægninger må nok tages med
Niels Hemmingsen var professor $i$ teologi, og Oldendorph skulle efter eget udsagn have slået ham $i$ disput.

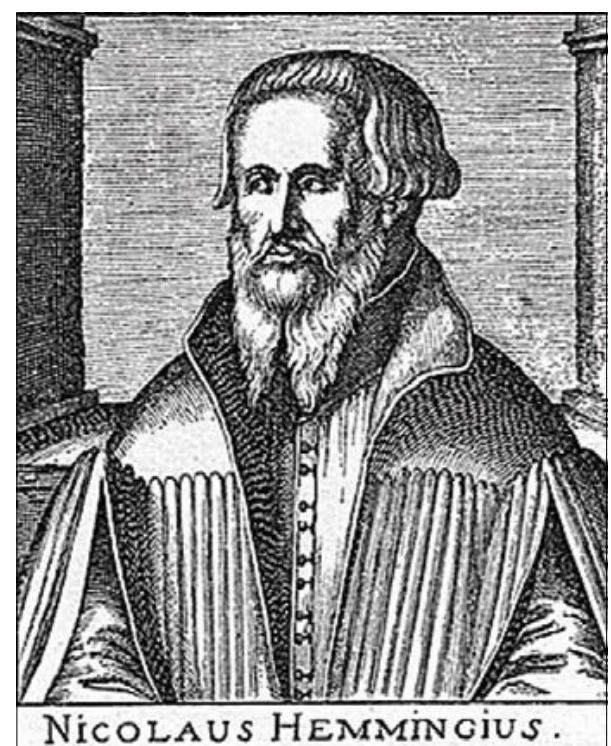

et gran salt. Tidligere har Oldendorph ikke sat sit lys under en skæppe, og det gør han heller ikke i denne sammenhæng. Niels Hemmingsen var en lærd teolog, der på dette tidspunkt havde været professor i græsk og teologi i knap 20 år. For læseren virker det næsten for godt til at være sandt, at en forhenværende kapellan fra Haderslev på kun 38 år kunne vinde over en af landets mest respekterede teologer.

Den 27. juli 1562 overværede Oldendorph doktor Rasmus Glads forelæsning. Pludseligt blev han grebet af en dødsfrygt, og Djævelen voldte ham åndelige anfægtelser. Dagen efter kom Djævelen igen for at anfægte hans tro, hvorefter præsten forlod København for at fri sig for Djævelen. På sin rejse hjem til Haderslev gjorde han stop i Sorø, og her så han en slange "som jeg straks trådte ihjel, og bagefter kunne jeg ikke finde den." 26

Præstens sygdom var nu blevet så slem, at han begyndte at hallucinere. Ved Antvorskov Kloster ankom Oldendorph meget svag, men om morgenen "brækkede jeg i haven mit sværd." ${ }^{27}$ Om han rent faktisk gik med et sværd vides ikke, men der kan være tale om et åndeligt sværd; gudstroen.

Syg af djævelskab og åndelige anfægtelser ankom Oldendorph til Haderslev den 6. august 1562 og lagde sig syg i sin broder Nicolaus' hus. Under overfarten ved Årøsund udråbte han en spådom om Dan- 
marks og Sveriges kommende straf på grund af deres foragt for Guds ord. Denne straf kom i 1563, da kong Frederik II af Danmark-Norge og kong Erik XIV af Sverige gik ind i Den Nordiske Syvårskrig. Fire dage senere udfriede Gud Oldendorph for sine åndelige lidelser ved hjælp af inderlig bøn. Indtil slutningen af maj 1563 forsøgte han at få tilsagn om en menighed af hertug Hans og Jørgen Boie, men uden held. Optegnelserne er her meget sporadiske og ikke særlig detaljerede sammenlignet med det senere bryllup og ægteskab.

\section{Forelskelse og bryllup}

En gudfrygtig og ærbar jomfru. Det var alt, hvad Johannes Oldendorph bad om af en hustru. Den 26. maj 1563 fik han sit ønske opfyldt, og forelskelsen nedenfor taler for sig selv.

"Den 26. maj i det Herrens år 1563 kom, mens min brodersøn Nicolaus var hos mig, til mig på mit værelse Catharina, Carsten Laursens datter, en gudfrygtig og ærbar jomfru, som for lang tid siden, helt fra mit første år i kapellanembedet i Haderslev, med en hemmelig, men from kærlighed havde sluttet mig ind i sit hjerte, hvilket jeg selv ikke vidste noget $\mathrm{om}$. Da hun kom ind til mig, hilste jeg på hende og sagde: Hvad ønsker du at meddele mig, min jomfru? For mit hjerte bankede, som om det var berørt af det ord, der på en forunderlig måde lød for mig: Se, din hustru er kommet til dig! Jeg undrede mig over, at dette blev indprentet i mit hjerte og sjæl, og jeg tænkte: Ske Guds vilje!"28

Samme dag lovede de hinanden troskab og lydighed i ægtestanden. Johannes Oldendorph var uden tvivl en forelsket mand på dette tidspunkt i sit liv. Hans beskrivelse af forelskelsens følelse er helt enestående i dens inderlighed, noget vi sjældent ser i erindringer og selvbiografier fra denne tid. Til sammenligning noterer præsten Absalon Pedersøn Beyer fra Bergen nøgternt i sin kapitelbog 1552-1572, at hans datter, Helvig, er død den 1. oktober 1563..$^{29}$ Det bliver formuleret med en ligegyldighed set med vores øjne i forhold til den sorg og smerte, som tabet af et barn må have voldt. Beyer var næppe en kynisk og kold mand. Stilen i dagbøger og selvbiografier i midten af 1500 -tallet var mere som i en skrivekalender med præcise optegnelser og ikke selvreflekterende erindringer om ens liv. Den sidstnævnte type selvbiografiske værker får vi først at se i begyndelsen af 1800-tallet. ${ }^{30}$ Johannes Oldendorphs selvbiografi har nogle karaktertræk, der gør bogen særegen for sin samtid og næsten anakronistisk.
Johannes og Catharina blev forlovet i Haderslev Bibliotek, og den 12. september 1563 stod brylluppet i Haderslev Domkirke. Kapellan Lago stod for vielsen, og festlighederne blev holdt ærbart og muntert. ${ }^{31}$

\section{Tilbageerobring af embede}

Oldendorphs fortælling holder herefter pause indtil november 1564, hvor han igen fatter pennen for at beskrive sine forsøg på at få et nyt embede. Han havde samtaler med hertug Hans flere gange om de bagtalelser, som han mente at være blevet udsat for ved hertugens hof. Hertugen svarede, at Oldendorph måske ikke længere duede til et embede, hvortil han udbrød med egne ord: "Så ukristeligt er jeg hos Eders fyrstelige Nåde ved skændige, æreløse løgne blevet fremstillet, at den gudløse hob udlægger min store smerte og sjæleangst til skam for mig. Gud skal nok finde dem; til ham vil jeg overlade denne sag og afgørelsen. ${ }^{\prime \prime 32}$ Hertug Hans den Ældre fik talt Oldendorph til ro og gav løfte om, at tilsagnet om et sognepræsteembede stadig stod ved magt. Han takkede, men påpegede, at han blev nødt til at forlade Haderslev og hertugdømmet, hvis han ikke kunne få underhold af hertugen. Han fik sit underhold, men bagtalte provst Jørgen Boie for at have lovet tilsagn på hertugens vegne uden samtykke.

Få dage efter døde sognepræsten i Øsby sogn, et stort og rigt sogn, som Oldendorph gik til hertugen for at få. Hertugen afviste at lade sådant et stort sogn gå til en så ukendt præst, men Oldendorph nævnte over for hertug Hans, at hvis han ikke fik en menighed ville hertugen indirekte

Hertug Hans den Aldre var ofte den Oldendorph vendte sig til, når han blev beskyldt for dårlig embedsførelse.

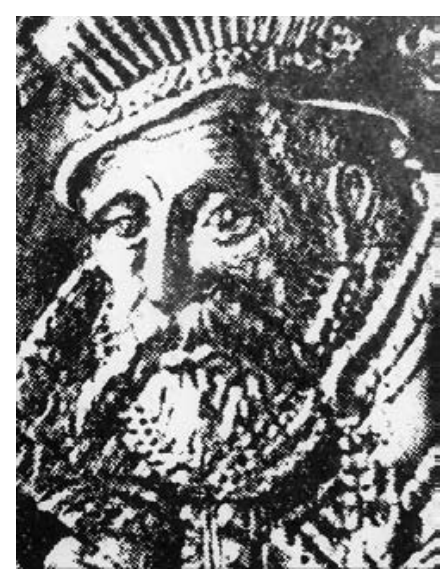


gøre Boie til en løgner ved ikke at opfylde hans tilsagn. Det må siges at være en vovet taktik over for selveste hertugen. Taktikken virkede dog for hertugen ændrede mening og svarede: "Vi vil se til det." ${ }^{\prime 33}$ Derefter fik Oldendorph ikke mere at høre fra hertugen om nyt embede. Først senere fandt Oldendorph ud af, at Johannes Strømesen fik Øsby sogn, men det varede ikke længe før præsten udviste tegn på sindssyge. ${ }^{34}$

Tiden gik, og Oldendorph blev far i marts 1565 til en lille datter: "Vor datter er altså født den 31. marts mellem kl. 6 og 7 om morgenen som en Guds gave og under hans bevarelse; ham skylder vi at sige evig tak for et sådant velskabt lille væsen." ${ }^{35}$ Pigen blev døbt den 1. april og fik navnet Elzebe efter Oldendorphs egen afdøde moder. Alt åndede nu fred og ro og på trods af hans manglende embede, virkede han nogenlunde rolig indtil midten af april 1566.

\section{Oldendorphs død}

Pesten ramte Haderslev allerede i 1565, men først i 1566 spredte den sig til resten af hertugdømmerne. Den 18. april 1566 begyndte Catharina at få feber, og dagen efter flød der blod fra hendes næsebor. Vrangforestillinger og fantasier kom til hende den 2. maj om natten, men hun kom til kræfter igen i begyndelsen af juni. Herefter følger en liste så lang af Oldendorphs familie, venner og bekendte, der bukkede under for byldepesten. Blandt de døde var Catharinas søster og far samt Oldendorphs niece.

Catharinas og Johannes' lille datter blev dødeligt syg i midten af august. Hendes fader var ude af sig selv af bekymring: "jeg begyndte med tårer at rette min brændende bøn for hende til Gud om, at han vilde lade hende blive i live." ${ }^{\prime 36}$ Kirugen kom nogle dage efter og fjernede et stykke af bylden, og et par dage efter fik hun det lidt bedre. Et snit i Catharinas og Johannes Oldendorphs albuevene var nødvendigt for at årelade dem begge, efter at pesten havde ramt dem selv. Kalenderen skriver 28. august, og de lå begge syge med pest i kroppen. To dage efter var det ved at være slut, og præsten var ved at udånde. Datteren skreg pludseligt, og Oldendorph vågnede med et sæt. Han blev reddet af barnegråd, men var alvorligt syg igen dagen efter. Her nedfældede han nogle sidste ord i sin selvbiografi, som sammenfattede hans livsmission: "jeg styrkede mig i Kristus, min Herre og Gud, med tilbagevisning af alle vranglærernes galskaber, som jeg altid i England, Tyskland, Danmark og Holsten har været modstander af, men jeg holder alene fast ved hele profeternes og apostlenes [lære]."37 En fremmed hånd har tilføjet den sidste linje i bogen: "Johannes Jacobsen Oldendorph døde den 2. september 1566." 38

\section{Kilde til dagligliv, hofliv, følelsesliv og mentalitetshistorie}

Johannes Oldendorphs livshistorie er her behandlet mere detaljeret end i tidligere fremstillinger. Det presserende spørgsmål er nu: hvad skal vi bruge ham til? Nogle af de passager, jeg har udeladt i gennemgangen af selvbiografien, handler ikke om ham selv, men begivenheder og personer omkring ham. Under alle omstændigheder er han en enestående kilde til dagliglivet i Haderslev i midten af 1500-tallet med sine mange små beretninger. Derfor er Johannes Oldendorphs selvbiografi som kilde til tilstandene i tiden efter reformationen vigtig trods forfatterens mentale tilstand.

Selvbiografien giver læseren et fint indblik i opfattelsen af de forskellige samfundslag og fænomener i Haderslev under hertug Hans den Ældre. Vi får synet på gale embedsmænd, når Oldendorph skriver om Øsby-præsten Johannes Strømesen, der løber nøgen rundt om fontænen på byens torv. ${ }^{39}$ Oldendorph nævner ikke, at Strømesen mister sit embede som sognepræst i Øsby. Det fortæller os, at Johannes Strømesen på trods af sin galskab fik lov til at fortsætte i embedet. Andre kilder fortæller os, at Johannes Strømesens sygdom tog til, så han i 1570 fik kapellanen hr. Jens til at hjælpe sig med sit embede. I 1571 ansøgte Øsbys menighed om, at få kapellanen som sognepræst, indtil Strømesen var helbredt. I 1573 søgte de igen om, at få hr. Jens som permanent sognepræst, da de "gik omkring som får uden hyrde." ${ }^{40}$ En tredje og sidste skrivelse fra 1575 indeholder modsat en ansøgning om at beholde Strømesen, i håb om at det kunne hjælpe hans helbredelse. Johannes Strømesen døde dog senere samme år.

Det har stået slemt til i Øsby sogn med deres præst, og i dagens Danmark ville det nok være utænkeligt at beholde en embedsmand med så mange klager hængende over hovedet. Strømesens sag viser os en mere lempelig opfattelse af psykisk ustabile, end man måske umiddelbart ville antage. Oldendorph selv tilhørte denne gruppe, så selvom selvbiografien fremstiller det anerledes, så fik han faktisk lov til at blive i sit embede som kapellan i lang tid på trods af de psykiske problemer, han havde.

Livet ved hoffet under hertug Hans den Ældre kender vi meget lidt til, da der kun findes få kilder om dette emne. Oldendorphs selvbiogra- 
fi giver os et vist indblik i de intriger og bagtalelser, der fandt sted ved hoffet. Dette kom Mikkel L. Jespersen frem til i sin bog om hertug Hans den Ældre fra 2010. Den 22. september 1560 opsagde magister Johannes Vortius sit sognepræsteembede i Haderslev. Om sin rejse fra Haderslev til Itzehoe skriver Oldendorph følgende: "I nærheden af Haderslev brast han [Johannes Vortius] sammen med sin hustru Margareta i gråd og klagede over Boie, Hieronymus' og sine andre misunderes bagtalelser, hadefuldhed, lumske angreb og nedsættende omtale ved hertug Hans' hof." ${ }^{41}$ Ifølge Oldendorph var hans overordnede udsat for stærk bagtalelse ved hoffet i Haderslev, hvilket fik ham til at bryde sammen. Formentligt er disse bagtalelser også grunden til Vortius' opsigelse. Om kritikken af Johannes Vortius var berettiget, finder vi sandsynligvis aldrig ud af. Bagvaskelsen kan være et praj om præstens uduelighed eller ren og skær misundelse.

Nødvendigheden af at skaffe sig hertugens gunst fremgår også af selvbiografien. I et forsøg på at smigre hertugen overrakte Oldendorph seks gudelige sange til provst Boie, for at fyrsten skulle se dem. ${ }^{42} \mathrm{Om}$ hertug Hans nogensinde så sangene, ved vi ikke, men Oldendorphs charmeforsøg viser tydeligt behovet for embedsmændenes gunst hos deres herrer. Selvom perioden efter reformationen i 1536 var præget af overgangen fra det gamle tjener-herre forhold til et mere moderne embedsmand-stat forhold, så betød det ikke enden på de gamle kneb for at indsmigre sig hos sine overordnede. Selvbiografien er hermed en god kilde til hoflivet i Haderslev efter reformationen.

Udover Johannes Oldendorphs skildringer af begivenheder omkring sig, er han en vigtig kilde til følelseslivet i midten af 1500-tallet. Han er nødvendigvis ikke repræsentativ for hele den datidige danske befolkning, men han er ét af de få indblik, vi har i en mands kærlighed til sin hustru og datter. I det ovenstående fremgår det tydeligt, at Oldendorph blev oprigtigt forelsket i Catharina Carstensdatter, da han så hende på Haderslevs bibliotek. Beskrivelsen af, hvordan de to gik ture og talte om Gud og tro, viser en dybt forelsket mand. En tilsvarende indgående personlig beskrivelse af en præsts kærlighedsliv finder vi næppe andre steder i Danmark på dette tidspunkt. I Italien har man lignende selvbiografiske skildringer af kærlighed i samme periode, eksempelvis i Benvenuto Cellinis selvbiografi. ${ }^{43}$

I skildringen af datterens fødsel viser Oldendorph endvidere glæde over at få en lille rask pige. Denne glæde giver nutidens læser et indblik $i$ en faders kærlighed til sit nyfødte barn - noget vi ellers tilskri- ver mere moderne mennesker. Myten om at piger var uønskede børn, som kun var til omkostning og besvær for familier i fortiden, gøres til skamme af Oldendorphs begejstring. Han er ganske vist ikke kongelig eller adelig og på den måde afhængig af at få en mandlig arving. Faderkærligheden demonstreres igen under pesten, hvor Elzebe bliver ramt. Vi får en hjerteskærende beretning om, hvorledes Oldendorph med tårer i øjnene beder til Gud om at lade sin datter leve. En skildring af forældresorg, der sjældent er set i samtidige selvbiografier og derfor gør Oldendorphs selvbiografi til en ret enestående kilde.

\section{Tør vi bruge ham?}

Som det blev beskrevet ovenfor, har faglitteraturen kritiseret Oldendorph. Kritikken er på mange punkter berettiget og går hovedsageligt på præstens psykiske ustabilitet og iltre personlighed. Selvom selvbiografien indeholder gode beretninger om dagligliv og følelsesliv hos en mand i 1500-tallet, så skal beretningerne dog bruges med omhu og påpasselighed. Netop på grund af hans psykiske tilstand må læseren tage flere af hans udsagn og skildringer med et gran salt. Mange af hans beretninger har vi ikke andre kilder til, eksempelvis samtalerne med hertug Hans den Ældre og provst Jørgen Boie. Hans ophold i Lambeth Palace er ikke bevidnet, hvad der dog ikke behøver at så tvivl om beretningens sandhed. Forholdene omkring Oldendorphs fyring som kapellan har ligeledes tvivlsomme træk, da ingen kilder kan bekræfte den "uretfærdige" måde han blev afskediget på.

Samlet set så står Johannes Oldendorphs selvbiografi ikke så stærkt som kilde til hans egne oplevelser, men derfor bør han ikke afskrives som kilde til de førnævnte emner. Som historiker må man også her stille sig selv spørgsmålet: Har forfatteren interesse i at lyve? I Oldendorphs tilfælde er det indlysende, at han selvfølgelig gerne har villet fremstille sig selv bedst muligt over for sine efterkommere, som skulle læse hans bog. I forhold til dagligliv, hofliv, kærlighedsliv og mentalitet må man overveje, hvorvidt Oldendorph har interesse $i$ at fordreje fremstillingen. Hvilken interesse kan han have haft $\mathrm{i}$ at lyve om sin store kærlighed? Hvorfor skulle han lyve om hofintrigerne, når de ikke engang berørte ham selv? Man skal selvfølgelig altid have in mente, at selvbiografier er erindringer, der ofte er nedskrevet langt senere end deres hændelse. I Oldendorphs tilfælde kan vi forsikre os om, at de seneste hændelser efter 1563 er nedfældet kort efter de er sket. Alt, der er sket før 1563, 
kan vi ikke være sikre på har stået klart i Oldendorphs hukommelse på nedskrivningstidspunktet. Vi husker alle sammen forskelligt, og mennesker har generelt tendens til at ændre deres erindringer over tid. Det kan skyldes dårlig hukommelse, benægtelse af et livstraume eller omskrivning af en hændelse for lettere at kunne leve med det. Oldendorph har givet været underlagt de samme menneskelige vilkår. Denne usikkerhed skal dog ikke afholde nogen fra at læse og anvende denne selvbiografi. Denne artikel har haft til formål at udlægge hele Johannes Oldendorphs selvbiografi og skabe en bredere forståelse af hans værks brugbarhed.

\section{KILDER:}

Utrykte:

Rigsarkivet: Haderslev Provsti. Kirkeregnskabsbog for Øsby Sogn 1564-1714 pakke 612-613

Rigsarkivet: Sønderjyske Fyrstearkiver, Hansborgarkivet. Lukkede breve, 1543-1580

Trykte:

Cellini, Benvenuto. Levned. Skrevet af ham selv. Oversat af Alfred Rottbøll. Kjøbenhavn: A. Christiansens Kunstforlag 1899.

\section{LITTERATUR:}

Achelis, T.O. Haderslev i gamle Dage - 12921626. Bind 1. Haderslev: Modersmaalets Trykkeri 1926

Baur, August. Zwinglis Theologie: Ihr Werden und ihr System. Band 1. Hildesheim 1983 [1885]

Billings, J. Todd \& I. John Hesselink (red.) Calvin's Theology and Its Reception - Disputes, Developments, and New Possibilities. Louisville 2012.

Favrholdt, M. Haderslev Latinskoles Historie, 1567-1967, Historisk Samfund for Sønderjylland. Haderslev: Modersmaalets Trykkeri 1966
Beyer, Absalon Pederssøn. Dagbok og Oration om Mester Geble. Ved Ragnvald Iversen. Bergen: Unversitetsforlaget Iversen. Bergen:
Oslo-Bergen 1963.

Oldendorph, Johannes. Johannes Oldendorphs Selvbiografi- Johannes Oldendorphs Selvbiografi - En præsteskæbne fra Haderslev $i$ hertug Hans den Ældres samfund for Sønderiylland. Tønder: Th. Lausens Bogtrykkeri 1966.

\section{NOTER:}

1 Denne artikel er en omarbejdning af mit speciale fra sommeren 2016 fra Syddansk Universitet skrevet under vejledning af lektor og ph.d. ved Institut for Historie, Lars Bisgaard.

2 Oldendorph 1966, s. 129

$\begin{array}{ll}2 & \text { Olde } \\ 3 & \text { Ibid. } \\ 4 & \text { Ibid. }\end{array}$

5 Rørdam 1867-1868, s. 247.

6 Achelis 1926, s. 78

7 Ibid., s. 87.

8 Oldendorph 1966, s. 6

9 Favrholdt, 1966, s. 51

10 Jespersen 2010, s. 90

11 Kohler 2005.

12 Baur 1983 [1885]

13 Wisløff 1985.

14 Billings \& Hesselink 2012.

15 Oldendorph 1966, s. 43.

16 Ibid, s. 45.

17 Ibid, s. 51

18 Ibid, s. 59 .

19 Ibid, s. 61

20 Ibid, s. 63.

21 Rigsarkivet, Lukkede Breve, 1562 s. 370 22 Oldendorph 1966, s. 65.

23 Ibid, s. 65 .

24 Ibid, s. 67

26 Ibid, s. 73

26 Ibid, s. 77

27 lbid.

28 Ibid, s. 91.

29 Beyer 1963, s. 40.

31 Oldendorph 1966, s. 99.

32 Ibid, s. 101.

33 Ibid, s. 105.

$34 \mathrm{Ibid}, \mathrm{s.} 123$.

35 Ibid, s. 113.

36 Ibid, s. 127.

37 Ibid, s. 131

38 Ibid.

39 Oldendorph 1966, s. 123

40 Rigsarkivet, Kirkeregnskabsbog

for Øsby Sogn 1564-1714.

41 Oldendorph 1966, s. 59.

42 Ibid, s. 81.

43 Cellini 1899.

\section{Zusammenfassung:}

Der Pfarrer Johannes Oldendorph (1524-1566) hatte ein schwieriges Temperament. Mehrmals wurde er von seinen Anstellungen als Kopist in England oder auch Kaplan in Hadersleben entlassen. Seine Autobiografie enthält viele Details und Beschreibungen des Alltagslebens in Hadersleben zur Zeiten Herzog Hans des Älteren (1521-1580). Die Autobiografie vermittelt einen seltenen Einblick in die Gedanken eines lutheranischen Pfarrers in der nachreformatorischen Zeit. Auch seine Gedanken zum Abendmahl und das Gefühlsleben eines Mannes im 16. Jahrhundert ist gut beschrieben. Aufgrund seiner unstabilen Psyche wird die Schrift Oldendorphs leider viel zu wenig genutzt. Mit angebrachtem Vorbehalt ist sie jedoch eine interessante zeitgenössische Quelle, die die Zeit, das Gefühlleben und auch die Hofintrigen im damaligen Hadersleben gut darstellt. 